\title{
Reality Works Through the Prism of Post-Postmodern Prose
}

(D.I. Drozdovskyi, Problematic-Thematic Units and Philosophical-Esthetical Parameters of the British Post-Postmodern Novel [Проблемно-тематичні комплекси ит фрілософсъко-естетичні параметри бримансъкого постпостмодерністсъкого роману]. Kiev: Samit-knyha, 2020)

\section{S U M M A RY}

The reviewer analyses the monograph Problematic-Thematic Units and Philosophical-Esthetical Parameters of the British Post-Postmodern Novel (Kyiv, 2020) written by Dmytro Drozdovskyi, a Ukrainian scholar from Taras Shevchenko Institute of Literature of the National Academy of Sciences of Ukraine, member of The European Society for the Study of English (Bulgarian branch). In the monograph, the author has outlined the theory of the post-postmodern novel based on the analysis of the key novels of contemporary British fiction (David Mitchell, Ian McEwan, Sarah waters, Mark 
Haddon, etc.). The review states that the Ukrainian scholar has developed the theory proposed by Fredric Jameson regarding the post-postmodern features of Cloud Atlas and also discusses the concept of meta-modernity as one of the sections in the post-postmodern literary paradigm in the UK. Drozdovskyi argues that meta-modernism cannot be the only term that explains all the peculiarities of contemporary British fiction, which also cannot be outlined as meta-modern but as post-postmodern. The scholar provides a new theory of the novel based on the exploitation of real and unreal historical facts and imagined alternative histories and multifaceted realities. Furthermore, the reviewer pays attention to the contribution this monograph has for world literary studies spotlighting the theory of literary meta-genre patterns, as Drozdovskyi provides a theory according to which literary periods can be divided into those in which the carnival is the dominant meta-genre pattern (like postmodernism) and those that exploit the mystery as the meta-genre pattern (post-postmodernism). The reviewer analyses the key thematic units explained by Drozdovskyi as the key ones that determine the semiosphere of the contemporary British novel (post-metaphysical and post-positivist thinking of the characters, medicalisation of the humanitarian discourse, and the representation of the temporal unity of different realities). The scholar also states that the post-postmodern British novel exploits the findings of German Romanticism and Kant's philosophy.

\section{Keywords}

philosophy of literature, British post-postmodern novel, Dmytro Drozdovskyi, carnival, mystery, German Romanticism, theory of the contemporary novel

The reviewed monograph deserves a closer examination considering its theoretical and practical advantages, and its innovative approach to the development of postmodernism in British novels. Its author is a theoretician of literature with considerable experience. Dmytro Drozdovskyi, a doctor of philology, has already proven himself a mature researcher; he is affiliated with the Shevchenko Institute of Literature, Department of Western and Slavic Literatures, National Academy of Sciences of Ukraine. It is important to note that his study Problematic-Thematic Units and Philosophical-Esthetical Parameters of the British Post-Postmodern Novel is a conceptually coherent project. He has defined the study subject clearly: the literary process (of writing novels) in one of Europe's leading literatures, British literature. The researcher convincingly discusses individual British novels that feature most emphatically the worldview and philosophical changes occurring in modern cultural theory in general, and in literary theory in particular.

For the study, he carefully established a reliable corpus of theoretical literature applicable to the problem area. The author mainly capitalises on the widely respected academic compendium of British theoretical thought The Routledge Companion to Twenty-First Century Literary Fiction, ${ }^{1}$ and on impor-

${ }^{1}$ The Routledge Companion to Twenty-First Century Literary Fiction, edited by Daniel O'Gorman and Robert Eaglestone (London-New York: Routledge, 2018). The compendium provides a complex outlook on the most representative tendencies in contemporary fiction in the UK and the USA. The concept of post-postmodernism occurs in various chapters of this anthology. 
tant studies (in terms of worldview) by noted foreign researchers ${ }^{2}$ as well as Ukrainian ones. ${ }^{3}$ Starting with fundamental studies, which had a major impact on the development of Ukrainian English/British studies, Drozdovskyi notes the transformations of tendencies occurring at the current stage of 21st-century British novel, e.g.: exploitation of mystery as a meta-genre phenomenon; combination of (pseudo)positivist and metaphysical worldviews, etc. The scholar discusses concepts within the area of 21st-century British literature of the traditions of scepticism ${ }^{4}$, philosophy of corporeality, ${ }^{5}$ and Kantianism ${ }^{6}$, and he has furthered and amplified Jameson's theses regar-

${ }^{2}$ These works of noted researchers include: Nealon, Jeffrey. Post-Postmodernism: or, The Cultural Logic of Just-in-Time Capitalism (Stanford: Stanford University Press, 2012). Nealon is the first one to propone the concept of post-postmodernism as a term for culture of the 21st century. Drozdovskyi develops Nealon's ideas in his monograph. See also: Jameson, Fredric. The Antinomies of Realism (London-New York: Verso, 2015); Jameson provides an outlook on "Cloud Atlas" and its post-postmodern composition. Drozdovskyi exploits the philosophy of Mitchell's novel and analyses the Kantian paradigm in the British novel. See also: Vermeulen, Timotheus, van den Akker, Robin. "Notes on Metamodernism," 1-14. Journal of Aesthetics and Culture, vol. 2, issue 1 (2010); Samuels, Robert. New media, cultural studies and critical theory after postmodernism. Automodernity from Zizek to Laclau (New York: Palgrave Macmillan, 2010). In his monograph, Drozdovskyi opens the discussion with Vermeulen and van den Akker regarding the term "metamodernism" explaining why it cannot be applied to the contemporary British novel and why this term does not include all the specific features of the post-postmodern British novel.

${ }^{3}$ These Ukrainian researchers include: Bovsunivska, Tetiana. Teoriia romanu; navch. posib. [Theory of the novel; teach. manual] (Kyiv: VPTs "Kyivskyi universytet," 2017). Taking into account Bovsunivska's theory of the post-postmodern novel, Drozdovskyi provides a systematic analysis of the British novels that cover the post-postmodern worldview and exploits a typology of features that give grounds for scholar's theory of the post-postmodern novel. See also: Tatarenko, Alla. Budivnychi muzyky i di-dzhei: funktsiia muzyky u formuvanni poetyky postmodernizmu ta postpostmodernizmu (na materiali serbskoi literatury) [Construction musicians and DJs: the function of music in the formation of poetics of postmodernism and post-postmodernism (based on the material of Serbian literature], 241-252. Musical texture of literary text Intermedial studios (edited by S. Matsenko) (Lviv: Apriori, 2017); Ovcharenko, Natalia. Post-colonial projections of Canadian prose (Odesa, 2018). Drozdovskyi develops his theory of the post-postmodern novel taking into account the scientific findings from other world literatures, like Serbian or Canadian. Besides, the scholar develops the theoretical implications of Tetiana Bovsunivska and Natalia Ovcharenko who represent the academic schools of Taras Shevchenko Kyiv National University and Shevchenko Institute of Literature of the National Academy of Sciences of Ukraine.

${ }^{4}$ Drozdovskyi in his monograph provides an academic discussion with Miroshnychenko developing and reestablishing her theory of scepticism in contemporary British fiction: Miroshnychenko, Liliia. Projections of skepticism in contemporary British novel: genesis, tradition, poetics (Kyiv, 2015). See also: Boinitska, Olha. English historiographical novel of the late twentieth and early twenty first centuries: the philosophy of the genre (Kyiv, 2016).

${ }^{5}$ Felix Shteinbuk in Ukrainian theory exploits the concept of "тілесно-міметичний метод" based on the analysis of literary texts that represent the literary process of late 20th century. Drozdovskyi develops Shteinbuk's theory grounding on the contemporary British novel. See also: Shteinbuk, Felix. Konverhentsiia toposu identychnosti u suchasnii svitovii literaturi [Convergence of the Identity Topos in Contemporary World Literature], 106-112. Naukovyi chasopys Natsional'noho pedahohichnoho universytetu imeni M. P. Drahomanova. Seriia 8: Filolohichni nauky (movoznavstvo i literaturoznavstvo) [Scientific Bulletin of M. Drahomanov Pedagogical University. Philological Issues (Linguistics and Literary Studies)] (Kyiv Vyd-vo NPU imeni M.P. Drahomanova, 2017), Vyp. 8.

${ }^{6}$ In Ukrainian literary discourse, Borys Shalahinov exploits the ideas of Kantian philosophy in the contemporary (modern and post-modern) texts of the 20th century. Drozdovskyi develops Shalahinov's views and reinforces his ideas about the carnival and mystery as literary meta-genres. See also: Shalahinov, Borys. Romantychnyi slovnyk: do istori i poniati terminiv rannoho nimetskoho romantyzmu [Romantic dictionary: towards a history of concepts and terms in 
ding the novel Cloud Atlas (first published in 2004) as one of the first British novels with clear post-postmodern philosophical and narrative features.

In the monograph, Drozdovskyi carefully studies twenty novels, including: Amsterdam, Atonement, Saturday, (Ian McEwan); Cloud Atlas (David Mitchell); The Little Stranger (Sara Waters), The Curious Incident of the Dog in the Night-time (Mark Haddon), and The Cleft (Doris Lessing), and discusses a series of key notions, undeniably important for the purposes of the development of comparative literary theory. Most of all, he identifies the carnival and the mystery as meta-genre forms of common culture and literature, specific for national literatures throughout various cultural and historical periods. To a considerable degree, the concept justifies the reinterpretation of certain genres in the history of literature, which is why Drozdovskyi's monograph may help researchers of other European literatures. Thus, its author has helped to correct the theory of periodisation of literary and historical epochs by complementing the findings of Dmitriy Lichaczow, ${ }^{7}$ Dmytro Ciževskij, ${ }^{8}$ and Дмитро Наливайко. ${ }^{9}$

According to Drozdovskyi, in light of the proposed theory of the carnival and the mystery as forms of meta-genres, which have the foundations of cultural and historical periods, it is also possible to differentiate post-postmodernism from postmodernism. The carnival proves a major worldview represented in postmodern works, while in post-postmodernism Drozdovskyi has found elements which confirm the notion of the mystery as the matrix which defines generic and narrative qualities, and in particular, he observes them in British novels written since 2000. This, in turn, is related to the presence of mythological plots and motifs. Nonetheless, Drozdovskyi concludes that today the mystery mainly updates the Christian paradigm (the motif of redemption in a protagonist's life) in works of literature, and the particularly significant notion (for Christianity) of resurrection expressed, e.g. in Cloud Atlas. Resurrection is a major theme of Easter and is key in the Christian world, as it reflects the model of a journey led by Christ.

Other qualities identified by Drozdovskyi which differentiate postmodernism from post-postmodernism include: epistemological inability to verify the reality (using the laws of mathematics, physics, biology, etc.) and characters in search of truth; the fact of combining several stories to create grand narratives; metaphysical determinism which explains the logic

early German Romanticism] (Kyiv: Vydavnycho-polihrafichnyit sentr NaUKMA, 2010); Shalahinov, Borys. "Karnaval i misteriia: rozdumy pro istorychni doli dvokh metaform yevropeiskoho mystetstva" [Carnival and Mystery: Reflections on the Historical Destiny of Two Metaforms of European Art], Vsesvit, no. 3-4 (2011): 249-255.

${ }^{7}$ Lichaczow, Dmitriy, Развитие русской литературы X-XVII веков, 1973, https://www. gumer.info/bibliotek_Buks/Literat/lihach/2_02.php Lichaczow classified all literary periods according to the fact whether they belong to the category "первинний стиль" or to the category "вторинний стиль."

${ }^{8}$ Ciževskij, Dmytro. "Outline of Comparative Slavic Literatures," in Survey of Slavic Civilization (Boston (Massachusetts), 1952), vol. I. Ciževskij developed his theory of literature as a one based on the principle of pendulum.

${ }^{9}$ Наливайко, Дмитро. Теорія літератури й компаративicmuка [Theory of literature and comparative literature studies] (Київ: Вид. дім «Києво-Могилянська академія», 2006). Nalyvaiko developed his classification of cultural-historical periods in Ukrainian literary theory. 
behind the functioning of the world and the certainty that its existence has some superior aim, which cannot be explained through science as human beings do not possess the appropriate tools to do that; a play with reality and, at the same time, a belief in the existence of meaning in that play; the utilisation of media and scientific topics and problems; representation of a new type of the Other (a character suffering from Asperger's syndrome or autism); the fact of combining various Romantic, modernist and postmodern ideas; the creation of characters longing for transcendence, who also profess Buddhist views and a scientist's vision of the world; and the use of Kant's philosophy and the notion of the unity of the universe.

The researcher set the ambitious task for himself of developing his argument on the basis of a broader corpus of texts. He manages to make his conclusions, which he has drawn from his study of British post-postmodern novels, convincing: from the works he has extracted the epistemological searches for characters and narrators focused on explaining how human reality works (corporeality and consciousness). It is noteworthy that in a 2019 article, i.e. one which was published prior to the publication of the monograph, Drozdovskyi attempted to prove the theory by comparing an Italian novel by Paolo Giordano The Solitude of Prime Numbers and a novel by Mark Haddon The Curious Incident of the Dog in the Night-Time. Naturally, singular comparisons are not enough to verify a theory, though one has to admit that tragic apotheoses are present in many modern works (I am referring to the utilisation of the motif of a tragic encounter of a protagonist with reality which results in a fundamental rethinking of the experience of "future" life, as it was the case in Shakespeare's King Lear). The author argues that a tragic apotheosis is one of the elements of the genre model of mystery, that it changes the existential parameters of both worldviews and the artistic image, which in turn indicates one's departure from the postmodern model.

In that sense, Drozdovskyi has expanded on the argument of Tetiana Pontitseva, ${ }_{1}^{10}$ who - as one of the first Ukrainian researchers - noticed that British post-postmodernism entails an epistemological immersion in existence. That means not only epistemological relativism, but also several other serious issues, which are definable in more detail by that specific prism of British post-postmodernism. Therefore, the author's contribution to literary theory seems significant. The researcher argues in favour of the accuracy of the term British literature. On the basis of the published published the material of British literature of the early 21st century, he develops a theoretical concept of the post-postmodern novel; he defines in detail the difference between post-postmodernism and meta-modernism ${ }^{11}$; he defines the philosophical specificity of the artistic post-postmodern space as a metabolic one; and he identifies the strategies of representation and reinterpretation of subjectivity in post-postmodern novels, which enables the

${ }^{10}$ Potnitseva, Tetiana. Izbrannyye istorii iz istorii literatury: monografiya. [Selected Stories from the History of Literature: monograph] (Kyiv: Izdatelskiy dom Dmitriya Burago, 2019).

${ }^{11}$ The concept of meta-modernism is discussed in the first manifesto of this cultural philosophy: Vermeulen, Timotheus, Van Den, Akker, Robin. "Notes on Metamodernism," Journal of Aesthetics and Culture, 2.0 (2010): 1-14. 
amplification of psychological traits in contemporary British novels. He notes that the characters in post-postmodern novels seek out ways to rationally overcome the chaos in their internal worlds as they cannot achieve that in their external worlds because they do not understand the rules which govern the functioning of consciousness and the body.

At the same time, the characters assume that more complex laws governing their realities (the universe and humans) exist. It should be noted that the presence of chaos in the realities surrounding the characters forces them to seek out autonomous resources in themselves (independently from any higher powers, belief in magic, or references to mysticism), which would enable them to overcome the chaos at least psychologically (Saturday by I. McEwan, The Curious Incident of the Dog in the Night-Time by M. Haddon, Cloud Atlas by D. Mitchell). Drozdovskyi attempted to reinterpret Kant's vision of the co-existence of humans and reality, which, per the philosopher's doctrine, is revealed to one's consciousness as chaos. That is why the consciousness of people who act are determined by the need to assign it meaning by transforming a "play with chaos" in post-postmodernism per the vertical paradigm and not the horizontal one which is specific for postmodernism. ${ }^{12}$ The author arrives at the conclusion that unlike in postmodern reality, what changes in post-postmodernism are the forms of intellectual organisation of reality, since the chaotic nature of life surrounding the characters becomes structurally complex (e.g. Cloud Atlas by D. Mitchell).

In summary, allow me to emphasise once more: in the monograph Problematic-Thematic Units and Philosophical-Esthetical Parameters of the British Post-Postmodern Novel, its author has accurately defined the discourse of rationalism (the motif of a sceptical consideration of reality by characters, and the political notions of colonialism, slavery, and mass consumption, as it has been done in Cloud Atlas) as a feature of the post-postmodern British novel. The researcher conducts a systematic analysis of the particular modes of thinking of the characters of the novel Cloud Atlas, in which protagonists possess a special ability enabling them to avoid social tensions and conflicts, and view the world in unity with the bio-physical and socio-psychological processes and phenomena. He has proven that the reinterpretations of the philosophical principles by Georg Wilhelm Friedrich Hegel and John Locke play a major role in British literary post-postmodernism. The reviewed work constitutes a major contribution to Ukrainian literary theory. It is undeniably valuable for its theoretical generalisations and the philosophical and aesthetic concepts presented in it. Regrettably, the researcher focusses

\footnotetext{
${ }^{12}$ Drozdovskyi, Dmytro. Problematic-thematic units and philosophical-esthetical parameters of the British post-postmodern novel [Проблемно-тематичні комплекси й фiлософосько-естетичні параметри британського постпостмодерністського роману], academic editor P. Iwanyszyn (Kyiv: Samit-knyha, 2020), 20. Drozdovskyi proves that the characters in the contemporary British novels demonstrate the intention to analyze the misunderstandings and life misfortunes they experience from the rational positions taking into account the idea of the Universe as a system. Understanding one element and its bonds it is possible to understand the surrounding elements and have a clear vision of the reality as a system. Post-postmodern British fiction exploits the idea of combination of (pseudo)positivism based on rational reasons and metaphysical feelings of the characters.
} 
less on the poetologic aspects of the British novel; they could certainly be the topic of his new studies. Drozdovskyi has enriched the Ukrainian literary science with the inclusion of a study of contemporary general literature, which is mainly focused on British literature - its character, and its philosophical and aesthetic originality.

\section{REF ER E N C ES}

Boinitska, Olha. English historiographical novel of the late twentieth and early twenty first centuries: the philosophy of the genre. Kyiv, 2016.

Bovsunivska, Tetiana. Teoriia romanu; navch. posib [Theory of the novel; teach. manual]. Kyiv: VPTs "Kyivskyi universytet," 2017.

Drozdovskyi, Dmytro. Problematic-thematic units and philosophical-esthetical parameters of the British post-postmodern novel [Проблемно-тематичні комплекси иे фрілософсько-естетичні параметри британського постпостмодерністського роману], academic editor P. Iwanyszyn. Kyiv: Samit-knyha, 2020.

Jameson, Fredric. The Antinomies of Realism. London-New York: Verso, 2015.

Miroshnychenko, Liliia. Projections of skepticism in contemporary British novel: genesis, tradition, poetics. Kyiv, 2015.

Nealon, Jeffrey. Post-Postmodernism: or, The Cultural Logic of Just-in-Time Capitalism. Stanford: Stanford University Press, 2012.

Ovcharenko, Natalia. Post-colonial Projections of Canadian Prose. Odesa, 2018.

Potnitseva, Tetiana. Izbrannyye istorii iz istorii literatury: monografiya [Selected Stories from the History of Literature: monograph]. Kiyev: Izdatelskiy dom Dmitriya Burago, 2019.

The Routledge Companion to Twenty-First Century Literary Fiction, edited by Daniel O'Gorman and Robert Eaglestone. London-New York: Routledge, 2018.

Samuels, Robert. New media, cultural studies and critical theory after postmodernism. Automodernity from Zizek to Laclau. New York: Palgrave Macmillan, 2010.

Shalahinov, Borys. "Karnaval i misteriia: rozdumy pro istorychni doli dvokh metaform yevropeiskoho mystetstva" [Carnival and Mystery: Reflections on the Historical Destiny of Two Metaforms of European Art]. Vsesvit, no. 3-4 (2011): 249-255.

Shalahinov, Borys. Romantychnyi slovnyk: do istori i poniati terminiv rannoho nimetskoho romantyzmu [Romantic dictionary: towards a history of concepts and terms in early German Romanticism]. Kiev: Vydavnycho-polihrafichnyit sentr NaUKMA, 2010.

Shteinbuk, Felix. "Konverhentsiia toposu identychnosti u suchasnii svitovii literaturi" [Convergence of the Identity Topos in Contemporary World Literature]. In Naukovyi chasopys Natsional'noho pedahohichnoho universytetu imeni M.P. Drahomanova. Seriia 8: Filolohichni nauky (movoznavstvo $i$ literaturoznavstvo) [Scientific Bulletin of M. Drahomanov Pedagogical 
University. Philological Issues (Linguistics and Literary Studies)], 106-112. Kyiv: Vyd-vo NPU imeni M. P. Drahomanova. 2017, Vyp. 8.

Tatarenko, Alla. "Budivnychi muzyky i di-dzhei: funktsiia muzyky u formuvanni poetyky postmodernizmu ta post-postmodernizmu (na materiali serbskoi literatury)" [Construction musicians and DJs: the function of music in the formation of poetics of postmodernism and post-postmodernism (based on the material of Serbian literature], 241252. Musical texture of literary text Intermedial studios (edited by S. Matsenko). Lviv: Apriori, 2017.

Vermeulen, Timotheus, Van Den, Akker, Robin. "Notes on Metamodernism," Journal of Aesthetics and Culture, 2.0. (2010): 1-14.

Mykoła Zymomria (30.11.1946) - Doctor of Philological Sciences, Professor of Germanic Studies, Comparative Literature and of Theory of literature; full professor, head of the Department of translation studies of Ivan Franko Drohobych State Pedagogical University (Ukraine).

E-mail: zimok@ukr.net 